\title{
Phormidium etoshii sp. nov. (Oscillatoriales, Cyanobacteria) described from the Etosha Pan, Namibia, based on morphological, molecular and ecological features
}

\author{
Pawan K. Dadheech ${ }^{1,2,3}$, Dale A. Casamatta ${ }^{4}$, Peter Casper ${ }^{1} \&$ Lothar Krienitz $^{1 *}$ \\ ${ }^{1}$ Leibniz-Institute of Freshwater Ecology and Inland Fisheries, Alte Fischerhütte 2, D-16775 Stechlin-Neuglobsow, Germany; \\ *Corresponding authore-mail: krie@igb-berlin.de \\ ${ }^{2}$ Central University of Rajasthan, Department of Microbiology, Bandarsindri 305801, Kishangargh, India \\ ${ }^{3}$ Government College, Department of Botany, Ajmer 305001, Rajasthan, India \\ ${ }^{4}$ University of North Florida, Department of Biology, Jacksonville, Florida 32224, U.S.A.
}

\begin{abstract}
An edaphic, filamentous, nonheterocytous cyanobacterium was collected from the Etosha Pan, Namibia. Based on multilocus sequencing of the 16S rRNA gene, beta and alpha subunits ( $c p c$ BA-IGS) of the phycocyanin operon and morphological and ecological features, we describe the new species Phormidium etoshii (Oscillatoriales). The taxon was differentiated from the phylogenetically closest taxa in morphological features and ecology.
\end{abstract}

Key words: cyanobacteria, Oscillatoriales, phylogeny, Phormidium, systematics, 16S rRNA, phycocyanin operon, Etosha Pan

\section{INTRODUCTION}

Cyanobacteria are the most widespread, diverse oxygenic photosynthetic prokaryotes, and are found in a wide range of habitats due to their broad ecological tolerances (Whitton \& Potts 2000; Waterbury 2006). It is estimated that cyanobacteria account for ca. $2.32 \times$ $10^{14} \mathrm{~g}$ fixed $\mathrm{C}$ on a global scale, representing $1 / 2000$ of the global biomass (GARCIA-PICHEL et al. 2003). Despite their prevalent occurrence and ecological importance, however, the alpha-level taxonomy of cyanobacteria is currently in the state of chaos (PERKERSON et al. 2011).

Cyanobacteria play important roles in terrestrial environments, especially in arid and semi-arid regions (CAMERon 1966; Belnap 2003; Yeager et al. 2007). Some of their ecological impacts include weathering, moisture retention, dust trapping, carbon and nitrogen fixation, influencing vascular plant establishment and stabilizing soils (see BELNAP 2003 for further discussion). Cyanobacteria tend to dominate microalgal populations in hot deserts (DE CHAZAL et al. 1992), with some taxa described as putatively endemic to these habitats (e.g., Mojavia, Spirirestis) (FlechtNer et al. 2002; ŘehÁKovÁ et al. 2007). However, there remains a great degree of confusion over the alpha-level biodiversity in these habitats due to past inconsistencies in cyanobacterial taxonomy (WynN-Williams 2000; Belnap 2003). For example, members of the Oscillatoriales (filamentous forms lacking specialized cells) are common in desert soils, but have historically been identified in the literature as the "Schizothrix" group sensu DrouET (1968). In his sweeping revisions, Drouet collapsed several cyanobacterial genera into $S$. calcicola, regardless of ecology in order to address phenotypically plastic taxa. These revisions were widely accepted in the United States as they greatly simplified cyanobacterial taxonomy. However, these revisions have repeatedly been shown to be overly simplistic (see comments by KomÁreK \& AnAgNostidis 2005).

The taxonomy of oscillatorian taxa is challenging due to their simple morphology and the lack of conspicuous traits (ANAGNOSTIDIS \& KOMÁREK 1988; KoMÁREK \& ANAGNOSTIDIS 2005). 16S rRNA gene analyses are commonly used to examine phylogenetic relationship within the cyanobacteria (WILMOTte et al. 1992; Nelissen et al. 1996; TuRner 1997; MarquardT \& Palinska 2007; Palinska et al. 2011), which has indicated that narrow, non-heterocystous filamentous are polyphyletic (WiLmotte 1994; Ishida et al. 2001; Comte et al. 2007; Johansen et al. 2008). Since the 16S rRNA gene may not be appropriate for resolving species relationships (CASAMATTA et al. 2005), other molecular marker such as the phycocyanin operon and ITS regions are being investigated to distinguish different taxa sharing similar morphological features (BAllot et al. 2004; Teneva et al. 2005; PremanandH et al. 2006; BALlot et al. 2008; STÜKEn et al. 2009; DADHEECH et al. 2010).

One of the most phylogenetically puzzling and misidentified genera of filamentous non-heterocystous cyanobacteria in need of phylogenetic revision is the 
classic genus Phormidium (CASAMATTA et al. 2005; KomÁreK 2010; Lopes et al. 2012). This genus has been described from freshwater, marine and terrestrial habitats. There are the terrestrial habitats which have received the least amount of research attention. Thus, the purpose of this manuscript is to describe a novel species of Phormidium collected from an understudied habitat: soils and water bodies of the Etosha Pan, Namibia. This region encompasses $>$ $5,000 \mathrm{~km}^{2}$ in its saline, endorheic basin which is the main habitat of the Etosha National Park. To find out the taxonomic identity and phylogentic position of the cyanobacterium prevailing as monospecific in a natural sample of Etosha Pan, we investigated the material using multilocus sequencing such as 16S rRNA gene, cpcBA-IGS locus and cyanotoxin producing genes along with morphological and ecological features.

\section{Materials And Methods}

Sample collection and light microscopy. Samples were collected on 12 November 2008 at Okandeka Spring (temperature $32{ }^{\circ} \mathrm{C}, \mathrm{pH} 9.55$, conductivity $8.8 \mathrm{mS} . \mathrm{cm}^{-1}$ and salinity $4.8 \%$ ), $20 \mathrm{~km}$ north of Okaukuejo, Etosha Pan, Namibia (GPS $18^{\circ} 59^{\prime} 39^{\prime \prime} \mathrm{S}, 15^{\circ} 52^{\prime} 05 \mathrm{E}$ ). Okandeka is a contact spring, with water seeping out above break points of the rock-layers of the underground and watering about 600 $m$ into the pan (Fig. 1).

The clonal culture of the studied cyanobacterium (KR2008/49) was established by isolating filaments with micropipettes and culturing in modified Bourrelly medium (KRIENITZ \& WIRTH 2006) at room temperature under a 14 $\mathrm{h}: 10 \mathrm{~h}$ light-dark regime. Initially, the strain started to grow well but unfortunately due to unknown reasons, we were unable to maintain living cultures for a long time. Thus, dried monospecific samples on cotton tissue were preserved as type material and deposited at the Botanical Museum in Berlin, Germany (B400040890). For additional comparisons to our Okandeka isolate, morphologically similar samples were collected from wet soil and water puddles at nine different sites of Etosha Pan.

Light microscopy studies were performed with samples fixed in formaldehyde using a Nikon Eclipse E600 microscope (Nikon Corporation Tokyo, Japan). Microphotographs were taken with a Nikon Digital camera DS-Fil and Nikon software NIS-Elements D. At least 50 measurements were conducted for calculating the size of cells.

Molecular methods: DNA extraction, PCR amplification, sequencing and phylogenetic analyses. The genomic DNA from initially grown strain (KR2008/49) and monospecific dried sample was extracted using Dynabeads DNA DURECT System I (Invitrogen/Dynal Biotech, Oslo, Norway) following the steps outlined in the manufacturer's manual. PCR of $16 \mathrm{~S}$ rRNA gene, and $c p c \mathrm{BA}-\mathrm{IGS}$ locus was performed in a Peltier Thermal Cycler PTC 200 (MJ Research Inc., San Francisco, USA). Each $20 \mu \mathrm{l}$ PCR cocktail contained $14.4 \mu \mathrm{l}$ of sterile water, $2.0 \mu \mathrm{l}$ of $10 \times \mathrm{PCR}$ buffer A (Qiagen, Hilden, Germany), $0.5 \mu 1$ of $20 \mathrm{mM}$ dNTPs (Qiagen) in an equimolar ratio, $1 \mu \mathrm{l}$ of a $10 \mu \mathrm{M}$ concentration of the forward primer, $1 \mu \mathrm{l}$ of a $10 \mu \mathrm{M}$ concentration of the reverse primer, $0.1 \mu \mathrm{l}$ of Taq DNA polymerase enzyme (5 $\mathrm{U} / \mu \mathrm{l}$ from Qiagen), and $1.0 \mu \mathrm{l}$ of sample DNA. The amount of template DNA was adjusted when necessary to generate sufficient PCR products for DNA sequencing. The forward primer $\mathrm{pA}$ and reverse primer B23S (cyanobacterial specific) were used for the amplification of 16S rRNA gene (EDWARDS et al. 1989; GKeLIs et al. 2005) with an annealing temperature of $50{ }^{\circ} \mathrm{C}$ for PCR protocol (BALLOT et al. 2008). The primers PCBf and PCar (NeILAN et al. 1995) were employed to obtain a partial sequence of $c p c \mathrm{BA}-\mathrm{IGS}$ locus of Etosha sample and $P$. cf. terebriforme KR2003/25. The PCR protocol for the amplification of phycocyanin operon was used as described previously (BALLOT et al. 2008). Amplified products were purified through Qiaquick PCR purification columns (Qiagen) according to manufacturer's protocol. Cleaned PCR products of dried sample were cloned using the Zero Blunt ${ }^{\circledR}$ Topo ${ }^{\circledR}$ PCR cloning kit 149 (Invitrogen, Germany) according to manufacturer's instructions. Positive colonies were selected, clones were PCR amplified and then cycle sequenced to retrieve the sequence of 16S rRNA gene fragment and $c p c \mathrm{BA}-\mathrm{IGS}$ locus.

The purified PCR product of 16S rRNA gene was sequenced using the primers $\mathrm{pA}, \mathrm{pC}, \mathrm{pE}, \mathrm{pDr}, \mathrm{pFr}, \mathrm{pHr}$ (EDWARDS et al. 1989) and $c p c$ BA-IGS region was sequenced using the same primers as used for the PCR on ABI 3100 Avant Genetic Analyzer using BigDye Terminator v3.1 Cycle Sequencing Kit (Applied Biosystems, Applera, Deutschland, GmbH, Darmstadt, Germany) as described in the manufacturer's manual.

The cyanobacterial sequences of $16 \mathrm{~S}$ rRNA gene were retrieved from nucleotide database of NCBI and aligned using software MUSCLE (EDGAR 2004). Alignment was checked visually using the Manual Sequence Alignment Editor Align v05/2008 (HEPPERLE 2008). Sequence similarity (identity matrix) of the closest sequences was calculated from all positions of the alignment including gaps using the program Align. The closest relatives to our sequences were detected using BLASTN (www.ncbi.nlm.nih.gov/blast). For the phylogenetic analyses, we initially selected a large group of sequences $(>1100 \mathrm{bp}$ ), and later a smaller subset was selected based on the relatedness of the sequences and excluding taxa of uncertain affiliation. For a synoptic view of the phylogenetic tree, only sequences from the Oscillatoriales, particularly Phormidium spp., were chosen. A tree was constructed by the maximum likelihood (ML) method using the program MEGA 5 (TAMURA et al. 2011) with default settings, applying a $\mathrm{K} 2+\mathrm{G}+\mathrm{I}$ model of nucleotide substitution, which gave the best fit to this dataset according to the Bayesian Information Criterion (BIC). Confidence values for the edges of the maximum-likelihood tree were computed by bootstrapping of 1000 replications. Maximum parsimony and neighbor joining trees were constructed using MEGA 5 (TAMURA et al. 2011) and compared the topologies of the obtained trees to establish and validate the phylogenetic position of the studied strain (data not shown). Anabaenopsis eleninii AB2006/20 (AM773307) was chosen as the outgroup taxon.

The phylogenetic tree of $c p c$ BA-IGS was constructed using the closest sequences to our sequences in BLASTN and following the steps employed for 16S rRNA gene analysis. The tree was prepared with $\mathrm{K} 2+\mathrm{G}$ model of nucleotide substitution, which gave the best fit to this dataset according to the Bayesian Information Criterion (BIC) using Arthrospira indica PD2002/gca (AY575944) as the outgroup 
taxon.

The genetic potential of the studied Phormidiumtaxon to produce a variety of toxins was assessed using different primer sets: HEPF/HEPR for $m c y \mathrm{E}$ (JungBLUT \& NeIlan 2006), FAA/RAA for mcyB (NeILAN et al. 1999), AnaC-genF/AnacC-genR for anacystin (RANTALA-YLINEN et al. 2011) and sxtA-F/sxtA-R for saxitoxin (AL-TEBRINEH et al. 2010). The PCR cycling protocol for each primer pairs was applied as previously described by the authors. The nucleotide sequences reported in this study have been deposited in the NCBI database under the GenBank accession numbers KC014068 (16S rRNA gene) and KC014069KC014070 (cpcBA-IGS).

\section{RESULTS}

Phormidium etoshii Dadheech, Casamatta, Casper et Krienitz sp. nov. (Figs 2, 5-8)

Diagnosis: Filamentae longae rectae vel undulatae, aeruginosae. Vagina incolorata vulgo invisibilis. Cellulae 4-7 um latae, 2-4 um longae. Filamentae ad septae inconstrictae vel plus minusve constrictae. Septae granulatae. Trichomata rotundatae vel attenuate ad apices sine calyptra. Reproductio hormogonis formatae cellulis necridis.

Filaments long, straight or curved, pale bright bluegreen. Sheath colourless mostly not visible. Cells 5.5 $( \pm 1.5) \mu \mathrm{m}$ wide and $3.0( \pm 1.0) \mu \mathrm{m}$ long. Filaments not or slightly constricted at the cross wall. Granulated at cross-walls. Apices of trichomes rounded or conical, without calyptra. Propagation by hormogonia formed by necridic cells.

Habitat: Hyposaline water puddles, springs and wet soil.

Type locality: Okandeka Spring, Etosha National Park, Namibia.

Holotype (designated here): monospecific dried sample (B400040890) in the Herbarium at the Botanical Museum at Berlin, Dahlem, Germany. An isotype is deposited at the herbarium of the National Botanical Research Institute at Windhoek, Namibia.

Etymology: the specific epithet (etoshii) reflects the occurrence of this species in the Etosha Pan in the Etosha National Park, Namibia.

Icona typica: a drawing of $P$. etoshii from the locus classicus (Fig. 9).

Morphologically most similar to Phormidium formosum (Bory ex Gomont) Anagnostidis et KomÁrek, but with undulating wider trichomes, and different phylogeny and ecology. Based on 16S rRNA gene sequence data, most similar to Phormidium acuminatum (GoMONT) ANAGNOSTIDIS et KOMÁrek, but differing in cell shape, formation of apical cell and ecology.

\section{Phenotypic features}

Phormidium etoshii is an edaphic cyanobacterium distributed through wide areas of the Etosha Pan (Fig. 1). On wetted soil of the saline-alkaline pan, P. etoshii contributed to the pale blue-green appearance of the clay (Fig. 3). In water puddles, the cyanobacterium established a brownish-green film at the bottom, later these aggregations came up to the water surface as thick mats. Filaments may produce dense, pale-green skins on the water surface with gas bubbles that gave a frogskin-like appearance (Fig. 4) and may be found as a free floating mass of filaments or attached to substratum of the pan. Filaments were variable from straight to curvy (Fig. 2). Trichomes were not attenuated or slightly attenuated in a few cases. Sheath was firm and rarely visible (Fig. 6). Cells were mainly wider (5.5 $\pm 1.5 \mu \mathrm{m})$ than long $(3.0 \pm 1.0 \mu \mathrm{m})$. Filaments were not (Figs $2,6,7$ ) or occasionally slightly constricted at the cross wall (Fig. 8). The shape of apical cell was quite variable as it was observed round (Figs 5,6), conicalstraight (Fig. 7), conical-bent (Fig. 8) without calyptra. The multiplication was documented by hormogonia formation with the help of necridic cells (Fig. 8). The phenotypic features of Phormidium etoshii and its phylogenetical closest taxa are summarized in Table 1.

\section{Phylogenetic analysis}

Identical sequences of the 16S rRNA gene and $c p c \mathrm{BA}-$ IGS locus were obtained from our isolated strain (KR2008/49) and clones of dried samples (data not shown) illustrating the monospecificity of the collected sample. A partial $16 \mathrm{~S}$ rRNA gene sequence (1268 bp) was obtained and compared with closely related taxa retrieved from GenBank database. Sequence analysis revealed that the sample showed $99 \%$ similarity in 16S rRNA sequence with Phormidium cf. terebriforme KR2003/25, uncultured bacterium clone TX4CB 70 , Phormidium sp. LEGE 06072, Oscillatoria acuminata PCC6304 and Phormidium sp. LEGE 06078. A ML tree revealed that Etosha sequence took position in a well defined clade mainly composed of other members of the genus Phormidium (Fig. 10). This clade encompassed taxa originated from varied habitats. Our sample formed a clearly separate lineage among taxa of this sub-clade (Fig. 10). Phormidium cf. terebriforme KR2003/25 was reported from hot springs at Lake Bogoria, Kenya while the origin of Oscillatoria acuminata PCC 6304 is not known.

We were able to get sequences of $458 \mathrm{bp}$ and $464 \mathrm{bp}$ of $c p c \mathrm{BA}-\mathrm{IGS}$ locus amplicon from the Etosha and $P$. cf. terebriforme taxon. Significantly comparable sequence of $c p c \mathrm{BA}-\mathrm{IGS}$ to the sequence of Etosha Pan taxon was not available in GenBank database. Moreover, the sequence of Etosha Pan strain exhibited 94\% similarity to Oscillatoria acuminata PCC6304 (AJ401186) and 96\% similarity to Phormidium cf. terebriforme (KR2003/25) sequenced in this study. This formed a distinct lineage in a well supported clade consisting $O$. acuminata and $P$. cf. terebriforme (Fig. $11)$. 


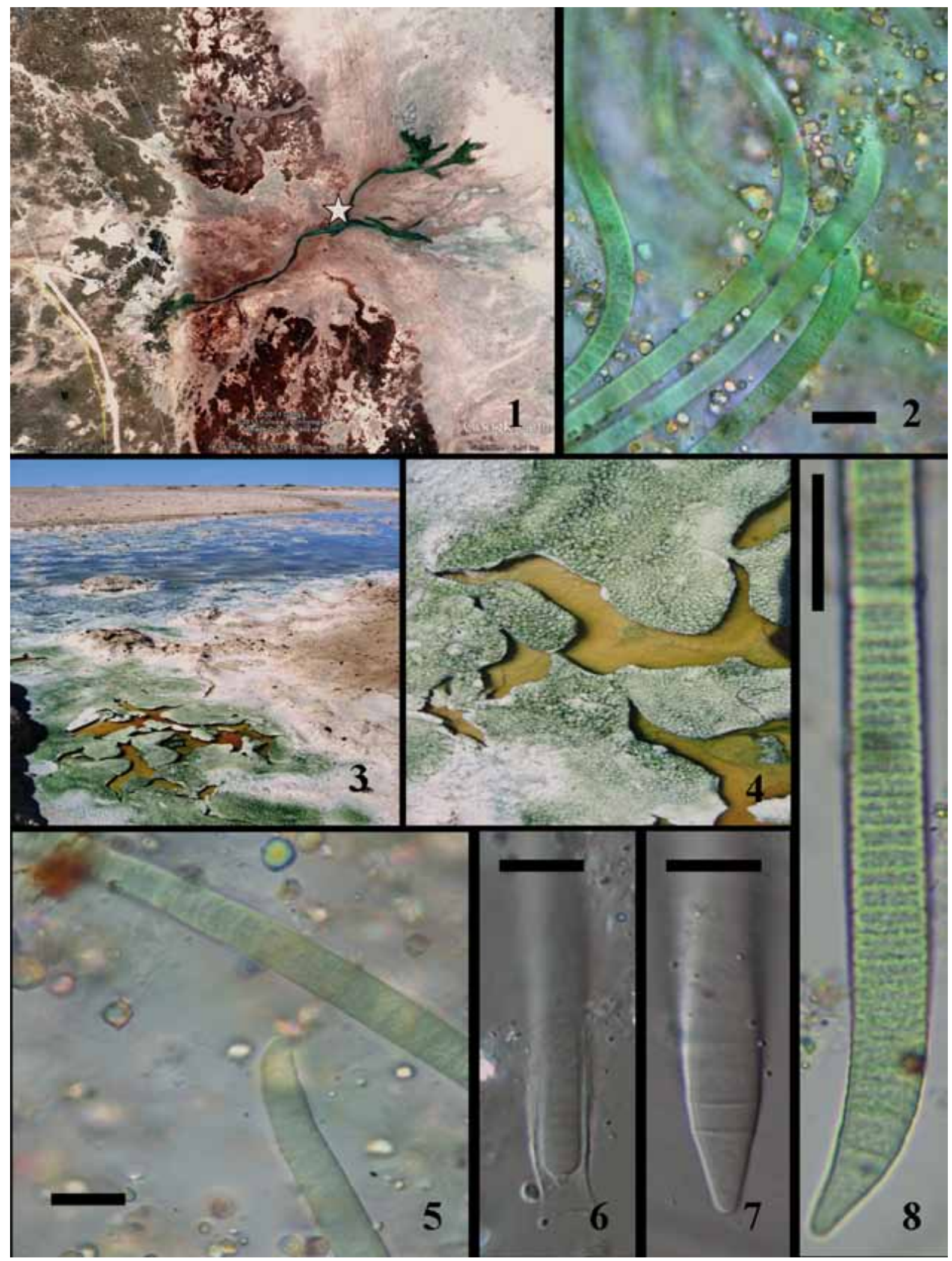

Figs 1-8. Habitat and microphotopraphs of Phormidium etoshii: (1) satellite view (from Google Earth) of the collection site at Okandeka Spring, Etosha Pan, Namibia. The spring (blue-green colored) is meandering into the pan. White star indicates the sampling point; (2) microphotograph of curvy filaments collected from wet soil; (3)overview on the Okandeke Spring which is covered with a skin of P. etoshii; (4) water surface with gas bubbles giving the cyanobacterial mat a frog-skin-like appearance; (5) filament with rounded slightly bent apical cell; (6) trichome with sheath; (7) filament with conical apical cell; (8) filament with conical-bent apical cell and necridic cell. Scale bars $10 \mu \mathrm{m}$. 

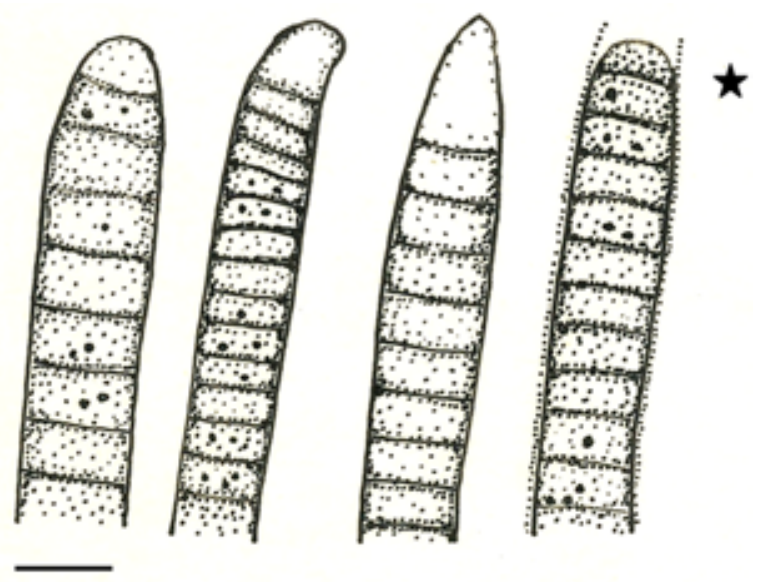

Fig. 9. Icona typica of Phormidium etoshii showing different shapes of apical cell. The iconotype is indicated by an asterisk. Scale bar $5 \mu \mathrm{m}$.

To detect potential cyanotoxins, PCR analyses were performed using several specific primer pairs. We did not get amplification for any genetic loci responsible for production of cyanotoxins such as microcystin, anatoxin-a and saxitoxin.

\section{Discussion}

Cyanobacteria are among the most ubiquitous, ecologically important photo-autotrophs, yet their identification is problematic due to their lack of distinguishing characteristics and poorly articulated alpha-taxonomy (CASAMATTA et al. 2005; KOMÁREK 2010). Numerous systematic revisions have been proposed to deal with issues relating to phenotypic plasticity, few distinguishing morphological features, and lack of habitat sampling. Recent surveys have revealed copious new taxa from previously unsampled habitats (e.g., KomÁReK \& ANAGNOSTIDIS 2005; TURICCHIA et al. 2009). It is from one such previously unsurveyed habitat, the Etosha National Park, Namibia, that we sampled and studied P. etoshii sp. nov.

One of the most problematic cyanobacterial genera in terms of phylogenetic assessment is Phormidium (Marquardt \& Palinska 2007; Comte et al. 2007; KOMÁREK 2010). This genus encompasses over 150 species, whose identifications often rely on environmentally inducible characters (e.g., sheaths) or transient forms, and numerous cryptic species have been postulated (CASAMATTA et al. 2005). However, recent molecular analyses have shown certain clades to share a high degree $(97.5 \%$ based on the $16 \mathrm{~S}$ rRNA gene) of genetic similarity (MARQUARDT \& PALINSKA 2007; Comte et al. 2007).

Many modern researchers advocate a total evidence or polyphasic approach to the elucidation of cyanobacterial systematic placements (COMTE et al.
2007; ScIUTO et al. 2011). In the polyphasic approach, the characterization of genera should be preliminarily based on molecular separation considering dissimilarity in $16 \mathrm{~S}$ rRNA gene sequence (about $95 \%$ or less genetic similarity) combined with at least one diacritical autapomorphic character (KoMÁREK 2010). Some new oscillatorian genera have been described and revised using this approach (ABED et al. 2002; SUDA et al. 2002; Siegesmund et al. 2008; Perkerson et al. 2011; StrunECKÝ et al. 2011; TATON et al. 2011; CASAmatTA et al. 2012; DADHEECH et al. 2012a, b; ZAMmit et al. 2012). However, species concepts are more complicated and as yet unclear in the cyanobacteria (KoMÁREK 2010). Fox et al. (1992) demonstrated that 16S rRNA gene similarity data are not sufficient to absolutely identify species in prokaryotes. It has been suggested that a single species of a cyanobacterium must be genetically, ecologically and morphologically uniform (KOMÁREK \& MAREŠ 2012).

The sequence (1268 bp) of our taxon shows 9899\% 16S rRNA gene similarity to other Phormidium taxa. The Etosha sequence forms a separate lineage in a big clade in that most of the taxa are genetically similar but with uncertain identification (Fig. 10). However, $P$. etoshii exhibits phylogenetic closeness to Phormidium acuminatum but it shows considerable morphological dissimilarities in cell size, cell shape and apical cell (Table 1). Likewise, our taxon also differs from $P$. terebriforme (KoMÁREK \& ANAGNOSTIDIs 2005) and $P$. cf. terebriforme (BALLOT et al. 2004) in morphological features such as constriction at cross wall, shape and attenuation of filament and shape of apical cell (Table 1). On the basis of terminal cell morphology, $P$. etoshii falls in group III of the Phormidium, while $P$. acuminatum and $P$. terebriforme belong to group I and II, respectively (KoMÁREK \& ANAGNOSTIDIS 2005). $P$. etoshii shows morphological similarities with $P$. richardsii but differs ecologically and in shape of apical cell as $P$. richardsii belongs to group I (KOMÁREK \& AnAGnOstidis 2005), while $P$. etoshii fits in group III. Our taxon is also morphologically more similar to $P$. formosum but displays undulating rather than straight filaments (KoMÁReK \& ANAGNOSTIDis 2005). Recently, five strains of $P$. formosum were isolated from epipelic habitat (Czech Republic) and sequenced for 16S rRNA gene (HAŠLER et al. 2012). Phylogenetic analysis reveals that $P$. etoshii and $P$. formosum are highly evolutionary divergent from each other (Fig. 10). Furthermore, the ecology of Etosha taxon is different from these strains. Though $P$. formosum has been recorded in brackish and saline habitats, this is regarded as an uncertain observation (KoMÁREK \& ANAGNOSTIDIS 2005). Additionally, $P$. acuminatum mainly reported from hypersaline thermal springs (KOMÁREK \& ANAGNOSTIDIS 2005) while $P$. cf. terebriforme was collected from hyposaline hot springs (BALLOT et al. 2004). Some new species of oscillatorian genera have been described those sharing $>99 \%$ sequence similarity of $16 \mathrm{~S}$ rRNA 
Table 1. Morphological and habitat characters of Phormidium etoshii and its phylogeneticaly closest relatives.

\begin{tabular}{|c|c|c|c|}
\hline Feature & Phormidium etoshii & $\begin{array}{l}\text { Oscillatoria acuminata PCC } \\
6304 \text { (=Phormidium acumina- } \\
\text { tum })^{1}\end{array}$ & $\begin{array}{l}\text { Phormidium cf. terebri- } \\
\text { forme }^{2}\end{array}$ \\
\hline Filament & Solitary, straight or curvy & $\begin{array}{l}\text { Solitary, usually straight or ir- } \\
\text { regularly screw like coiled at the } \\
\text { ends }\end{array}$ & $\begin{array}{l}\text { Solitary, straight to undulat- } \\
\text { ing }\end{array}$ \\
\hline Sheath & Hyaline, colorless & Hyaline, colorless & Detail not available \\
\hline Cell width $(\mu \mathrm{m})$ & $5.5 \pm 1.5$ & $5.0 \pm 1.0$ & $5.5 \pm 0.5$ \\
\hline Cell length $(\mu \mathrm{m})$ & $3.0 \pm 1.0$ & $6.0 \pm 2.0$ & $3.0 \pm 1.0$ \\
\hline Cell shape & Mainly wider than long & Mostly longer than wide & Mainly isodiametric \\
\hline Apical cell type & $\begin{array}{l}\text { Round, conical; straight or bent; } \\
\text { without calyptra }\end{array}$ & $\begin{array}{l}\text { Acute-conical, thorn-like or } \\
\text { needlelike; without calyptra }\end{array}$ & Rounded; without calyptra \\
\hline $\begin{array}{l}\text { Constriction at cross } \\
\text { wall }\end{array}$ & Not or slightly constricted & Not or slightly constricted & Constricted \\
\hline Habitat & Saline-alkaline & Hypersaline thermal springs & Hyposaline hot springs \\
\hline
\end{tabular}

${ }^{1}$ KomÁré \& Anagnostidis (2005); ${ }^{2}$ Ballot et al. (2004).

gene but differed in morphology and ecological preferences (CASAMATTA et al. 2005; BoHUNIKÁ et al. 2011). P. etoshii is not only distinct in morphological features from phylogentically related taxa but also has different ecology as it is originated from a unique saline-alkaline pan.

The IGS region and flanking subunits beta $(c p c \mathrm{~B})$ and alpha $(c p c \mathrm{~A})$ can be used as a marker for characterization of various members of cyanobacteria (Neilan et al. 1995; Bolch et al. 1996; BitTEnCOURTOliviera et al. 2001; Ballot et al. 2008; StÜKen et al. 2009), including Phormidium (Teneva et al. 2005; Premanandh et al. 2006). Sequences of $c p c$ BA-IGS locus of phycocyanin operon were used as suitable markers for distinguishing Nostoc species or strains (TenEva et al. 2012) and suggested as a marker to assign a molecular species concept in the genus Arthrospira (DADHEECH et al. 2010). We compared $c p c$ BA-IGS sequence of our taxon with the only closest sequence (94\%) of a taxon P. acuminatum available in GenBank and newly sequenced $P$. cf. terebriforme KR2003/25 $(96 \%)$ in this study. The sequence of Etosha sample showed considerable difference in percent similarity and also has a distinct lineage in phylogenetic tree. In the $c p c \mathrm{BA}-\mathrm{IGS}$ phylogeny, the Etosha sequence exhibit relatedness to $P$. cf. terebriforme whereas it is more related to $P$. acuminatum in the $16 \mathrm{~S}$ rRNA gene phylogeny.

The Etosha pan is hypo-saline, but salinity values vary considerably depending on evaporation (HAMmER et al. 1983). Therefore, water sources with lower salt content are essential for the survival of the numerous animals in the Etosha National Park.
Okandeka Spring is the only waterhole north of Okaukuejo. The spring water is slightly hyposaline and the water supply is relatively stable and attracts wildlife for drinking (OsBorne \& Versfeld 2004). Even flamingos are coming occasionally to drink and wash the feathers.

Etosha Pan is a breeding site of the Lesser Flamingos (BERRY 1972; Versfeld 2006). Worldwide, only six sites are used for breeding by the Lesser Flamingos: Lake Natron (Tanzania), Etosha Pan (Namibia), Makgadikgadi-Pan (Botswana), Kamfers Dam (South Africa) as well as two pans in the 'Little Rann of Kachchh' (India) (CHILDREss et al. 2008). The feeding grounds of Lesser Flamingos in Namibia are beside Etosha Pan several water bodies and lagoons near Walvis Bay. At both sites the main food resource consists of benthic diatoms and filamentous cyanobacteria (KRIENITZ 2009). Mass developments of the cyanobacterium Arthrospira fusiformis which is the main food resource of Lesser Flamingos in the soda lakes of East Africa, are missing in Namibia. Therefore, $P$. etoshii can act as an alternative food for flamingos. PCR-based detection of potential cyanotoxins production by cyanobacteria is being successfully employed as a tool for characterization of oscillatorian taxa (DADHEECH et al. 2012b; LOPES et al. 2012). In our investigations, we used selective primers to detect genes for the synthesis of cyanotoxins (microcystin, anatoxin-a and saxitoxin), but did not find any of these genes in P. etoshii.

We describe Phormidium etoshii as a new species of Oscillatoriales based on differential phylogeny in $16 \mathrm{~S}$ rRNA gene and $c p c \mathrm{BA}-\mathrm{IGS}$ locus; morphological 


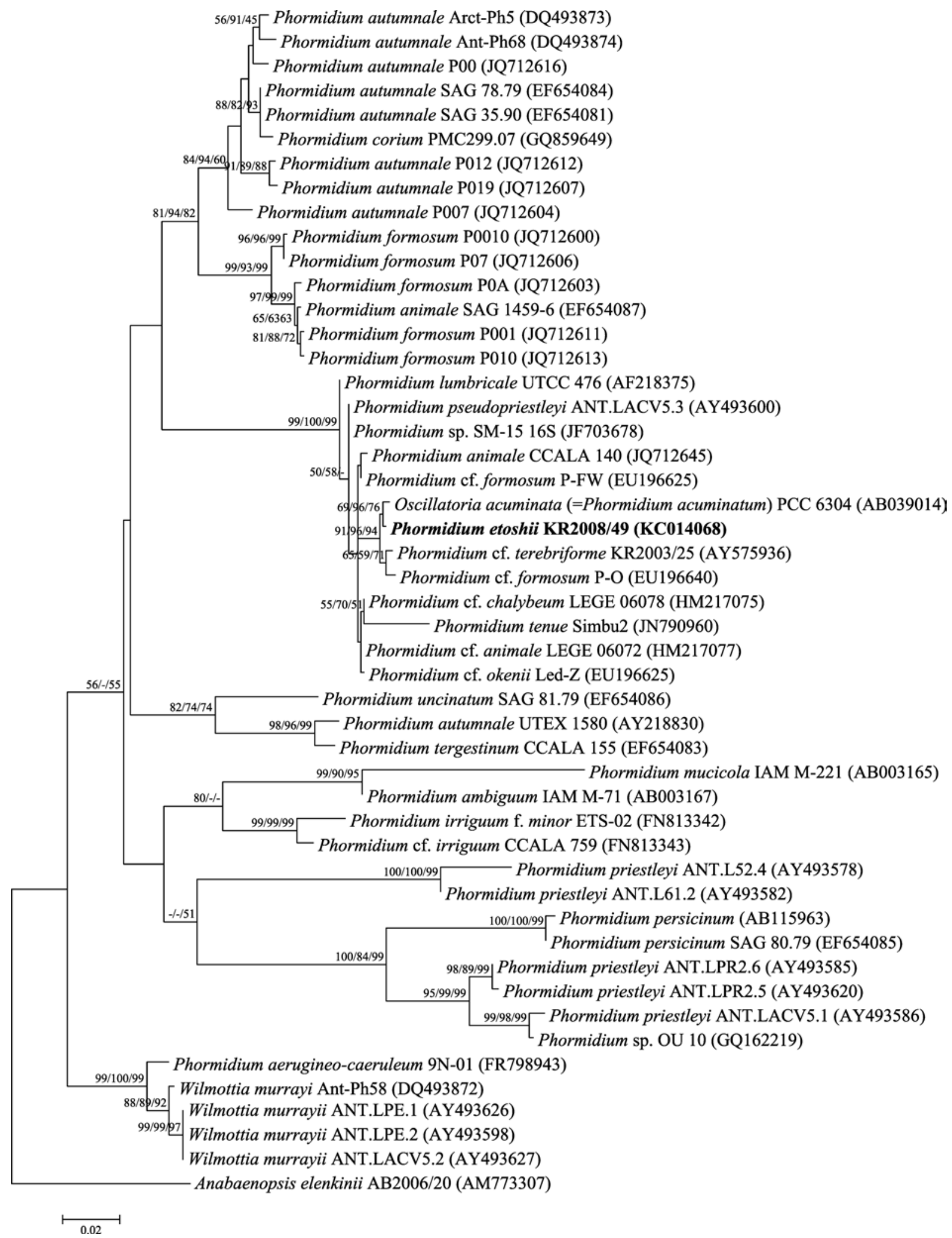

Fig. 10. Maximum likelihood phylogenetic tree based on 16S rRNA gene sequences (size $1000 \mathrm{bp}$ ). Numbers above branches indicate bootstrap support $(>50 \%)$ from 1,000 replicates and are given in the following order: maximum likelihood/neighbor joining/maximum parsimony. The novel species is in bold font. 


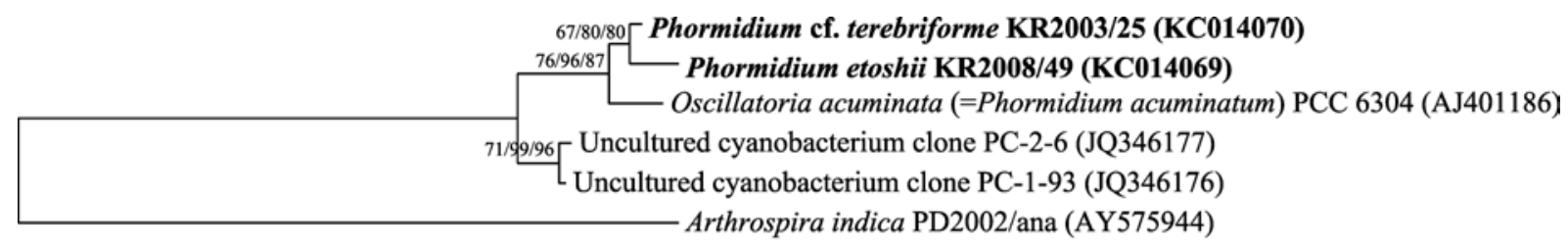

0.05

Fig. 11. Maximum likelihood phylogenetic tree based on $c p c$ BA-IGS sequences (size $\sim 450$ bp). Numbers above branches indicate bootstrap support $(>50 \%)$ from 1,000 replicates and are given in the following order: maximum likelihood/neighbour joining/maximum parsimony. The novel species and a taxon sequenced in this study are in bold font.

and ecological dissimilarities to phylogentically close taxa.

\section{ACKNowledgements}

We thank the Government of Namibia, the Ministry of Environment and Tourism, for permission to carry out this research (Permit No.1310/2008). We are grateful to the colleagues from the Etosha Ecological Institute, in particular the Chief Science Warden, Wilferd Versfeld for their collaboration.

\section{REFERENCES}

Abed, R.M.M.; Garcia-Pichel, F. \& Hernandez-Marine, M. (2002): Polyphasic characterization of benthic, moderately halophilic, moderately thermophilic cyanobacteria with very thin trichomes and the proposal of Halomicronema excentricum gen. nov., sp. nov. - Arch. Microbiol. 177: 361-370.

Al-Tebrineh, J.; Mihali, T.K.; Pomati, F. \& Neilan, B.A. (2010): Detection of saxitoxin-producing cyanobacteria and Anabaena circinalis in environmental water blooms by quantitative pcr. Appl. Environ. Microb. 76: 7836-7842.

Anagnostidis, K. \& KomÁReK, J. (1988): Modern approaches to the classification system of cyanophytes, 3 Oscillatoriales. - Algological Studies 50-53: 327432.

Ballot, A.; Dadheech, P.K. \& Krienitz, L. (2004): Phylogenetic relationships of Arthrospira, Phormidium and Spirulina from Kenyan and Indian waterbodies. - Algological Studies 113: 37-56.

Ballot, A.; Dadheech, P.K.; Hannde, S. \& Krienitz, L. (2008): Morphological and phylogenetic analysis of Anabaenopsis abijatae and Anabaenopsis elenkinii (Nostocales, Cyanobacteria) from tropical inland water bodies. - Microb. Ecol. 55: 608-618.

Belnap, J. (2003): Biological soil crusts in deserts: a short review of their role in soil fertility, stabilization, and water relations. - Algological Studies 109: 113-126.

Berry, H.H. (1972): Flamingo breeding on the Etosha Pan, South West Africa, During 1971. - Madoqua Ser. I, 5: 5-31.

Bittencourt-Oliveira, M.C.; Oliveira, M.C. \& Bolch, C.J.S. (2001): Genetic variability of some Brazilian strains of Microcystis aeruginosa complex (Cyanophyceae/ Cyanobacteria) using the nucleotide sequence analysis of the intergenic spacer and flanking regions from $c p c \mathrm{BA}-$ phycocyanin operon. - J. Phycol. 37:
810-818.

Bolch, C.J.; Blackburn, S.I.; Neilan, B.A. \& Grewe, P.M. (1996): Genetic characterization of strains of cyanobacteria using PCR-RFLP of the $c p c B A$ intergenic spacer and flanking regions. - J. Phycol. 32: 445-451.

BohunickÁ, M.; Johansen, J.R. \& FučíkovÁ, K. (2011): Tapinothrix clintonii sp. nov. (Pseudanabaenaceae, Cyanobacteria), a new species at the nexus of five genera. - Fottea 11: 127-140.

Cameron, R.E. (1966): Desert algae: soil crusts and diaphanous substrata as algal habitats. - pp. $1-41$, Jet Propulsion Lab Technical Report.

Casamatta, D.A.; Johansen, J.R.; Vis, M.L. \& Broadwater, S.T. (2005): Molecular and morphological characterization of ten polar and near-polar strains within the Oscillatoriales (Cyanobacteria). - J. Phycol. 41: 421-438.

Casamatta, D.; Stanić, D.; Gantar, M. \& Richardson, L.L. (2012): Characterization of Roseofilum reptotaenium (Oscillatoriales, Cyanobacteria) gen. et sp. nov. isolated from Caribbean black band disease. Phycologia 51: 489-499.

Childress, B.; NAGY, S. \& Hughes, B. (2008): International single species action plan for conservation of the Lesser Flamingo (Phoenicopterus minor). - In: CMS Technical Series No. 18 AEWA Technical Series No. 34. - pp. 59, Bonn, Germany.

Comte, K.; Sabacka, M.; Carre-Mlouka, A.; Elster, J. \& KomÁreK, J. (2007): Relationships between the Arctic and the Antarctic cyanobacteria; three Phormidium-like strains evaluated by a polyphasic approach. - FEMS Microbiol. Ecol. 59: 366-376.

Dadheech, P.K.; Ballot, A.; Casper, P.; Kotut, K.; Novelo, E.; Lemma, B.; Pröschold, T. \& Krienitz, L. (2010): Phylogenetic relationship and divergence among planktonic strains of Arthrospira (Oscillatoriales, Cyanobacteria) of African, Asian and American origin deduced by $16 \mathrm{~S}-23 \mathrm{~S}$ ITS and phycocyanin operon sequences. - Phycologia 49: 361-372.

DadheEch, P.K.; Abed, R.M.M.; Mahmoud, H.; Mohan, K.M. \& KRIENITZ, L. (2012a): Polyphasic characterization of cyanobacteria isolated from desert crusts, and the description of Desertifilum tharense gen. et sp. nov. (Oscillatoriales). - Phycologia 51: 260-270.

Dadheech, P.K.; Mahmoud, H.; Kotut, K. \& Krienitz, L. (2012b): Haloleptolyngbya alcalis gen. et sp. nov., a new filamentous cyanobacterium from the soda lake Nakuru, Kenya. - Hydrobiologia 691: 269-283.

de Chazal, N.M.; Smaglinski, S. \& Smith, G.D. (1992): Methods involving light variation for isolation of 
cyanobacteria: characterization of isolates from central Australia. - Appl. Environ. Microbiol. 58:3561-3566.

Drouet, F. (1968): Revision of the classification of the Oscillatoriaceae; Monogr. 15 Acad. - 370pp., Natural Sci. Philadelphia.

EDGAR, R.C. (2004): MUSCLE: multiple sequence alignment with high accuracy and high throughput. - Nucleic Acids Res. 32: 1792-1797.

Edwards, U.; Rogall, T.; Blocker, H.; Emde, M. \& BotTGer, E.C. (1989): Isolation and direct complete nucleotide determination of entire genes. Characterization of a gene coding for $16 \mathrm{~S}$ ribosomal RNA. - Nucleic Acids Res. 17: 7843-7853.

Flechtner, V.R.; Boyer, S.L.; Johansen, J.R. \& DeNoble, M.L. (2002): Spirirestis rafaelensis gen. et sp. nov. (Cyanophyceae), a new cyanobacterial genus from arid soils. - Nova Hedwigia 74: 1-24.

Fox, G.E.; Wisotzkey, J.D. \& JurTshuk, P. (1992): How close is close: 16S rRNA sequence identity may not be sufficient to guarantee species identity. - Int. J. Syst. Bacteriol. 42: 166-170.

Garcia-Pichel, F.; Belnap, J.; Neuer, S. \& Schanz, F. (2003): Estimates of global cyanobacterial biomass and its distribution. - Algological Studies 109: 213-228.

Gkelis, S.; Rajaniemi, P.; Vardaka, E.; Moustaka-Gouni, M.; Lanaras, T. \& Sivonen, K. (2005): Limnothrix redekei (Van Goor) Meffert (cyanobacteria) strains from Lake Kastoria, Greece form a separate phylogenetic group. - Microb. Ecol. 49: 176-182.

Hammer, U.T.; Shamess, J. \& Haynes, R.C. (1983): The distribution and abundance of algae in saline lakes of Saskatchewan, Canada. - Hydrobiologia 105: 1-26.

Hašler, P.; Dvoř́á, P.; Johansen, J.R.; Kitner, M.; OndřEJ, V. \& PoulíčKovÁ, A. (2012): Morphological and molecular study of epipelic filamentous genera Phormidium, Microcoleus and Geitlerinema (Oscillatoriales, Cyanophyta/Cyanobacteria). Fottea 12: 341-356.

HepPerLe, D. (2008): Align, multisequence alignment editor Ver. 05/2998 Ssequentix - Digital DNA Processing. Klein Raden, Germany.

Ishida, T.; Watanabe, M.M.; Sugiyama, J. \& Yokota, A. (2001): Evidence for polyphyletic origin of the members of the orders of Oscillatoriales and Pleurocapsales as determined by $16 \mathrm{~S}$ rDNA analysis. - FEMS Microbiol. Lett. 201: 79-82.

Johansen, J.R.; Olsen, C.E.; Lowe, R.L.; FučikovÁ, K. \& Casamatta, D.A. (2008): Leptolyngbya species from selected seep walls in the Great Smoky Mountains national park. - Algological Studies 126: 21-26.

Jungblut, A.D. \& NeIlan, B.A. (2006): Molecular identification and evolution of the cyclic peptide hepatotoxins, microcystin and nodularin, synthetase genes in three orders of cyanobacteria. - Arch. Microbiol. 185: 107-114.

KomÁrek, J. \& Anagnostidis, K. (2005): Cyanoprokaryota, 2. Teil: Oscillatoriales. - In: BÜDEL, B.; GÄRTNER, G.; Krienitz, L. \& Schagerl, M. (eds): Süsswasserflora von Mitteleuropa, vol. 18/2. - 759pp., Elsevier, München.

KomÁReK, J. (2010). Recent changes (2008) in cyanobacteria taxonomy based on a combination of molecular background with phenotype and ecological consequences (genus and species concept). -
Hydrobiologia 639: 245-259.

KomÁreK, J. \& MAREš, J. (2012): An update to modern taxonomy (2011) of freshwater planktic heterocytous cyanobacteria. - Hydrobiologia 698: 327-351.

KRIEnitZ, L. (2009): Algal food quality of Lesser Flamingos. - Roan News, Windhoek 2009: 41-43.

KrienitZ, L. \& WirTh, M. (2006): The high content of polyunsaturated fatty acids in Nannochloropsis limnetica (Eustigmatophaceae) and its implication for food web interaction, freshwater aquaculture and biotechnology. - Limnologica 36: 204-210.

Lopes, V.R.; Ramos, V.; Martins, A.; Sousa, M.; Welker, M.; Antunes, A. \& VAsconcelos, V.M. (2012): Phylogenetic, chemical and morphological diversity of cyanobacteria from portuguese temperate estuaries. - Mar. Environ. Res. 73: 7-16.

Marquardt, J. \& Palinska, K.A. (2007): Genotypic and phenotypic diversity of cyanobacteria assigned to the genus Phormidium (Oscillatoriales) from different habitats and geographical sites. - Arch. Microbiol. 187: 397-413.

Neilan, B.A.; Jacobs, D. \& Goodmann A. (1995): Genetic diversity and phylogeny of toxic cyanobacteria determined by DNA polymorphisms within the pycocyanin locus. - Appl. Environ. Microbiol. 61: 3875-3883.

Neilan, B.A.; Dittmann, E.; Rouhiainen, L.; Bass, R.A.; Schaub, V.; Sivonen, K. \& BöRner, T. (1999): Nonribosomal peptide synthesis and toxigenicity of cyanobacteria. - J. Bacteriol. 181: 4089-4097.

Nelissen, B.; DeBaere, R.; Wilmotte, A. \& DeWachter, R. (1996): Phylogenetic relationships of nonaxenic filamentous cyanobacterial strains based on $16 \mathrm{~S}$ rRNA sequence analysis. - J. Mol. Evol. 42: 194200.

Osborne, T.O. \& Versfeld, W.D. (2004): Etosha National Park-Guidebook to the Waterholes and Animals. Ventura Publications, Windhoek.

Palinska, K.A.; Deventer, B.; Hariri, K. \& Lotocka, M. (2011): A taxonomic study on Phormidium-group (cyanobacteria) based on morphology, pigments, RAPD molecular markers and RFLP analysis of the 16S rRNA gene fragment. - Fottea 11: 41-55.

Perkerson, R.B.; Johansen, J.R.; KováčIK, L.; Brand, J.; KaštovskÝ, J. \& CAsamattA, D.A. (2011): A unique pseudanabaenalean (cyanobacteria) genus Nodosilinea gen. nov. based on morphological and molecular data. - J. Phycol. 47: 1397-1412.

Premanandh, J.; Priya, B.; Teneva, I.; Dzhambazov, B.; Prabaharan, D. \& Uma, L. (2006): Molecular characterization of marine cyanobacteria from the Indian subcontinent deduced from sequence analysis of the phycocyanin operon $(c p c \mathrm{~B}-\mathrm{IGS}-c p c \mathrm{~A})$ and 16S-23S ITS region. - J. Microbiol. 44: 607-616.

Rantala-Ylinen, A.; Kana, S.; Wang, H.; Rouhiainen, L.; Wahlsten, M.; Rizzi, E.; Berg, K.; Gugger, M. \& Sivonen, K. (2011): Anatoxin-a synthetase gene cluster of the cyanobacterium Anabaena sp. strain 37 and molecular methods to detect potential producers. - Appl. Environ. Microbiol. 77: 7271-7278.

Řeháková, K.; Johansen, J.R.; Casamatta, D.A.; Xuesong, L. \& VinCENT, J. (2007): Morphological and molecular characterization of selected desert soil cyanobacteria: three species new to science including Mojavia pulchra gen. et sp. nov. - Phycologia 46: 481-502. 
Sciuto, K.; Rascio, N.; Andreoli, C. \& Moro, I. (2011): Polyphasic characterization of ITD-01, a cyanobacterium isolated from the Ischia Thermal District (Naples, Italy). - Fottea 11: 31-39.

Siegesmund, M.A.; Johansen, J.R.; Karsten, U. \& Friedl, T. (2008): Coleofasciculus gen. nov. (cyanobacteria): Morphological and molecular criteria for revision of the genus Microcoleus Gomont. - J. Phycol. 44: 1572-1585.

Strunecký, O.; Elster, J. \& KomÁrek, J. (2011): Taxonomic revision of the freshwater cyanobacterium "Phormidium" murrayi = Wilmottia murrayi. Fottea 11: 57-71.

Stüken, A.; Campbell, R.J.; Quesada, A.; Sukenik, A.; DADHEeCh, P.K. \& Wiedner, C. (2009): Genetic and morphologic characterization of four putative cylindrospermopsin producing species of the cyanobacterial genera Anabaena and Aphanizomenon. - J. Plankton. Res. 31: 465-480.

Suda, S.; Watanabe, M.M.; Otsuka, S.; MahaKahant, A.; Yongmanitchai, W.; Nopartnaraporn, N.; LiU, Y. \& DAY, J.G. (2002): Taxonomic revision of water bloom-forming species of oscillatorioid cyanobacteria. - Int. J. Syst. Evol. Microbiol. 52: 1577-1595.

Tamura, K.; Peterson, D.; Peterson, N.; Stecher, G.; Nei, M. \& Kumar, S. (2011): MEGA 5: Molecular evolutionary genetics analysis using maximum likelihood, evolutionary distance, and maximum parsimony methods. - Mol. Biol. Evol. 28: 27312739.

Taton, A.; Wilmotte, A.; Smarda, J.; Elster, J. \& KomÁrek, J. (2011): Plectolyngbya hodgsonii: a novel filamentous cyanobacterium from antarctic lakes. Polar Biol. 34: 181-191.

Teneva, I.; Dzhambazov, B.; Mladenov, R. \& Schirmer, K. (2005): Molecular and phylogenetic characterization of Phormidium species (Cyanoprokaryota) using the cpcB-IGS-cpcA locus. - J. Phycol. 41: 188-194.

Teneva, I.; Stoyanov, P.; Mladenov, R. \& Dzhambazov, B. (2012): Molecular and phylogenetic characterization of two species of the genus Nostoc (cyanobacteria) based on the cpcB-IGS-cpcA locus of the phycocyanin operon. - J. BioSci. Biotech. 1: 9-19.
Turicchia, S.; Ventura, S.; Komárková, J. \& KomÁreK, J. (2009): Taxonomic evaluation of cyanobacterial microflora from alkaline marshes of northern Belize. 2. Diversity of oscillatorialean genera. - Nova Hedwigia 89: 165-200.

Turner, S. (1997): Molecular systematics of oxygenic photosynthetic bacteria. - Plant Syst. Evol. (Suppl.) 11: 13-52.

VERSFELD, W.D. (2006): Flamimgo breeding activity on the Etosha Pan - further sign of a good rain season. Namibia Crane News 22: 2.

WATERBURY, J. (2006): The cyanobacteria-isolation, purification and identification the prokaryotes. - In: Dworkin, M.; Falkow, S.; Rosenberg, E.; Schleifer, K.-H. \& Stackebrandt, E. (eds): The Prokaryotes, Vol. 4 . - pp. 1053-1073, Springer, New York.

Whitton, B.A. \& Potts, M. (2000): Introduction to the Cyanobacteria. The Ecology of Cyanobacteria. Kluwer Academic Publishers, Dordrecht, the Netherlands.

Wilmotte, A.; Turner, S.; Vandepeer, Y. \& Pace, N.R. (1992): Taxonomic study of marine oscillatoriacean strains (cyanobacteria) with narrow trichomes. 2. Nucleotide-sequence analysis of the $16 \mathrm{~S}$ ribosomal RNA. - J. Phycol. 28: 828-838.

Wilmotte, A. (1994): Molecular Evolution and Taxonomy of the Cyanobacteria. - Kluwer Academic Press, Boston.

WynN-Williams, D.D. (2000): The Ecology of Cyanobacteria: Their Diversity in Time and Space. - In: Whitton, B.A. \& PotTs, M. (eds): The Ecology of Cyanobacteria. - pp. 341-366, Kluwer Academic Publishers, Dordrecht, the Netherlands.

Yeager, C.M.; Kornosky, J.L.; Morgan, R.E.; Cain, E.C.; Garcia-Pichel, F.; Housman, D.C.; Belnap, J. \& KuSKE, C.R. (2007): Three distinct clades of cultured heterocystous cyanobacteria constitute the dominant $\mathrm{N}_{2}$-fixing members of biological soil crusts of the Colorado Plateau, USA. - FEMS Microbiol. Ecol. 60: 85-97.

Zammit, G.; Billi, D. \& Albertano, P. (2012): The subaerophytic cyanobacterium Oculatella subterranea (Oscillatoriales, Cyanophyceae) gen. et sp. nov.: a cytomorphological and molecular description. - Eur. J. Phycol. 47: 341-354.

(C) Czech Phycological Society (2013)

Received November 19, 2012

Accepted January 24, 2013 